Ethos (Jurnal Penelitian dan Pengabdian Masyarakat): 220-225

\title{
SOSIALISASI TEKNOLOGI INDUSTRI NUTRIENT BLOCK TERNAK RUMINANSIA
}

\author{
${ }^{1}$ Winaruddin, ${ }^{2}$ Teuku Zahrial Helmi, ${ }^{3}$ Rusli \\ ${ }^{1,2,3}$ Fakultas Kedokteran Hewan Universitas Syiah Kuala \\ Email: winaruddin2008@gmail.com
}

\begin{abstract}
Series of Community Services (Product Based) was conducted to develop and extend these livestock feeding technologies to improve ruminants productivity for participant of Community Services. The methode used were training and discussion to the farmers. Mineral mixture prepared as per specifications is being used for manufacturing urea-molasses multi-nutrient blocks (UMMBs) by the cold process in an hand press block-making machine. The size of the block for this project $340 \mathrm{~mm} \times 150 \mathrm{~mm} \times 100 \mathrm{~mm}$. Using the machine, three hundred blocks are made at one day. By feeding UMMBs to smallholder beef cattle in areas it was found that live-weight $(L W)$ and body condition score tended to be improved. Sequent pilot farm studies have shown that the farmers are interested in adopting this technology since production benefits are self evident. Government Livestock Extension workers have also been trained to further extend the use of this technology.
\end{abstract}

Keywords: Berbasis produk, mesin hand press, nutrient block, ternak ruminansia

\begin{abstract}
Abstrak. Serangkaian Pengabdian Masyarakat (Berbasis Produk) dilaksanakan untuk mengembangkan dan memperluas teknologi pakan ternak ruminansia ini untuk meningkatkan produktivitas ternak ruminansia bagi peserta Pengabdian Masyarakat. Metode yang digunakan adalah pelatihan langsung dan diskusi kepada petani. Campuran mineral yang disiapkan sesuai spesifikasi formula untuk pembuatan multi-nutrient urea-molasses block (UMMB) melalui proses dingin dan dicetak dalam mesin hand press pembuat block. Ukuran block untuk kegiatan ini adalah $300 \mathrm{~mm} \times 150 \mathrm{~mm} \times 80 \mathrm{~mm}$. Menggunakan mesin hand press, tiga ratus blok dapat dibuat dalam waktu satu hari. Ternak percontohan mengalami peningkatan bobot hidup dan skor kondisi tubuh setelah pemberian UMMB. Program percontohan ini telah membuktikan bahwa petani sangat vtertarik untuk mengadopsi teknologi ini. Pera Petugas Penyuluh Peternakan juga telah dilatih untuk memperluas penggunaan teknologi ini.
\end{abstract}

Kata kunci: Berbasis produk, mesin hand press, nutrient block, ternak ruminansia

\section{Pendahuluan}

Usaha ternak sapi di desa-desa Kecamatan Krueng Barona Jaya Kabupaten Aceh Besar merupakan potret bagaimana usaha ternak sapi potong (pedaging) di Indonesia merupakan salah satu sumber pangan yang sangat dibutuhkan berupa daging. Produktivitas sapi potong masih sangat memprihatinkan karena jumlahnya masih jauh dari target yang diperlukan konsumen. Hal ini menyebabkan kebutuhan daging belum dapat terpenuhi. Sapi yang dipotong untuk konsumsi lokal, bukan dihasilkan dari sistem peternakan yang produktif dan efisien, melainkan dari sistem peternakan tradisional dengan produktivitasnya rendah. Ada tiga faktor penyebab 
utama yakni penurunan angka kelahiran, tingginya angka kematian pedet, dan rendahnya net growth rate. Ketiga faktor tersebut disebabkan oleh defisiensi pakan dan penyakit.

Pemberian pakan hijauan semata tidak cukup untuk memacu kenaikan berat badan yang ideal. Mitra peternak menyadari bahwa pemberian pakan tambahan berupa complete feed addtive sangat diperlukan. Jenis pakan ini masih diimpor, maka harganya kurang terjangkau oleh para peternak dan pemberiannya selalu diabaikan. Kendala ini mendorong mitra home industri pakan ternak untuk merintis untuk pengolahan complete feed addtive. Namun varian bentuk pakan yang diolah sangat terbatas pada peruntukan tertentu, demikian pula dari aspek kualitas dan kuantitas masih di bawah standar. Untuk itu mitra industri logam dapat membantu dengan membuat alat mesin press tangan yang digunakan untuk pembuatan pakan pakan tersebut. Sehingga mitra industri pakan ternak dapat mencetak pakan dalam jumlah banyak dalam waktu yang singkat.

Tujuan kegiatan ini adalah untuk meningkatkan pengetahuan dan keterampilan terutama para peternak mengenai teknologi pakan nutrient block untuk meningkatkan produksi ternak sapi mereka. Selain itu juga meningkatkan jiwa kewirausahaan para mitra mengembang industri alat dan pakan ternak kepada masyarakat sekitar desa. Sehingga permasalahan produktivitas dan cara membalikkan potret tersebut menjadi lebih baik.

Kegiatan ini sangat bermanfaat bagi petani peternak yang kurang memperoleh pengetahuan dan keterampilan praktis, terutama mengenai teknologi pakan nutrient block untuk meningkatkan produksi ternak sapi, sehingga diharapkan akan dapat mengatasi kekurangan akan ternak sapi. Pada akhirnya dapat meningkatkan kelangsungan usaha peternakan sekaligus meningkatkan kesejahteraan petani peternak.

\section{Metode Pelaksanaan}

Transfer IPTEKS oleh Tim Pelaksana kegiatan Pengabdian kepada Masyarakat berbasis produk dilakukan pada tiap tahapan dengan menggunakan prinsip bahwa setiap inovasi yang diterima oleh Mitra (1), Mitra (2) dan Mitra (3) dilakukan melalui proses, mendengar, mengetahui, mencoba, mengevaluasi, menerima, meyakini, dan melaksanakan. Melalui proses tersebut inovasi dapat diadopsi secara berkesinambungan, serta target sasaran mempunyai kemampuan untuk melakukan analisis terhadap perkembangan usahanya. Agar setiap proses berlangsung dengan baik, maka penyampaian inovasi kepada Mitra ditempuh melalui tahapan penjelasan, diskusi, praktek serta dilakukan tahapan pendampingan. Dalam melaksanakan kegiatan pengabdian ini, tim pelaksana membagi kegiatan sebagai berikut:

1. Tahap I

Pengenalan dan pelatihan teknologi produk pakan nutrient block untuk pengembangan usaha peternakan ruminansia kepada kelompok mitra, agar mendapatkan wawasan dan pemahaman yang baik tentang keuntungan usaha berbasis pemanfaatan teknologi pakan.

2. Tahap II

Pemilihan peralatan produksi dan perawatan untuk menghasilkan produk yang berkualitas dan berkesinambungan.

\section{Tahap III}

Pelatihan teknik pembuatan pakan nutrient block sesuai dengan formula untuk membantu para mitra dalam penyediaan pakan alternatif yang memiliki nilai gizi yang cukup tinggi, dengan biaya produksi yang rendah. Pada tahap ini para mitra diperkenalkan penggunaan teknologi pembuatan pakan nutrient block, berupa mesin pencetak pakan, mesin 
mixer pakan, mesin pengering, teknik pengemasan dan cara pemberiannya pada ternak. Berikut gambar rangakaian proses pelaksanaan:
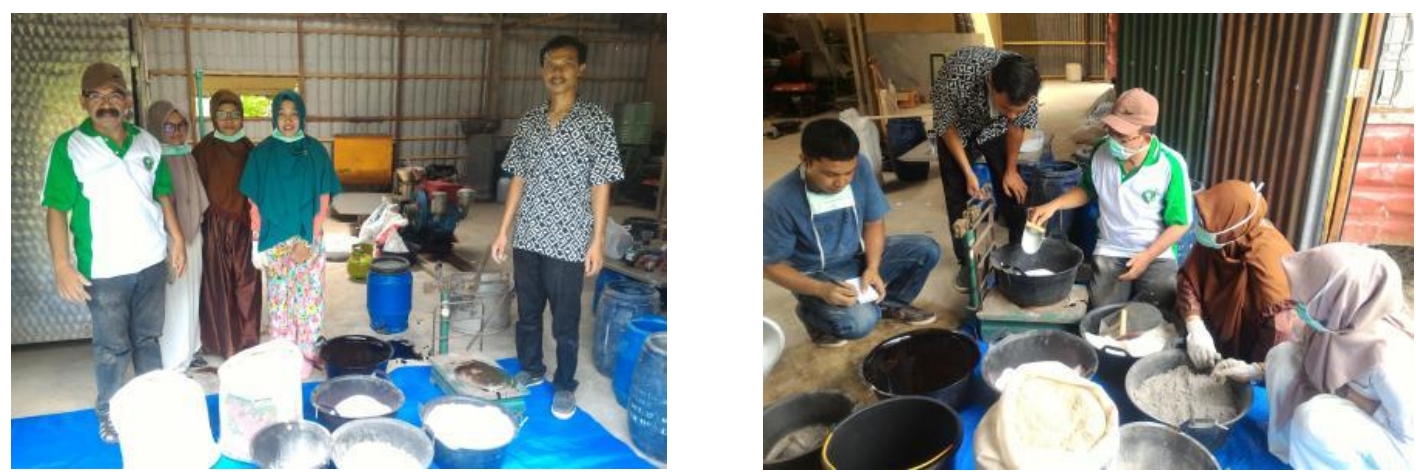

Gambar 1. Bahan dasar pembuatan nutrient block.
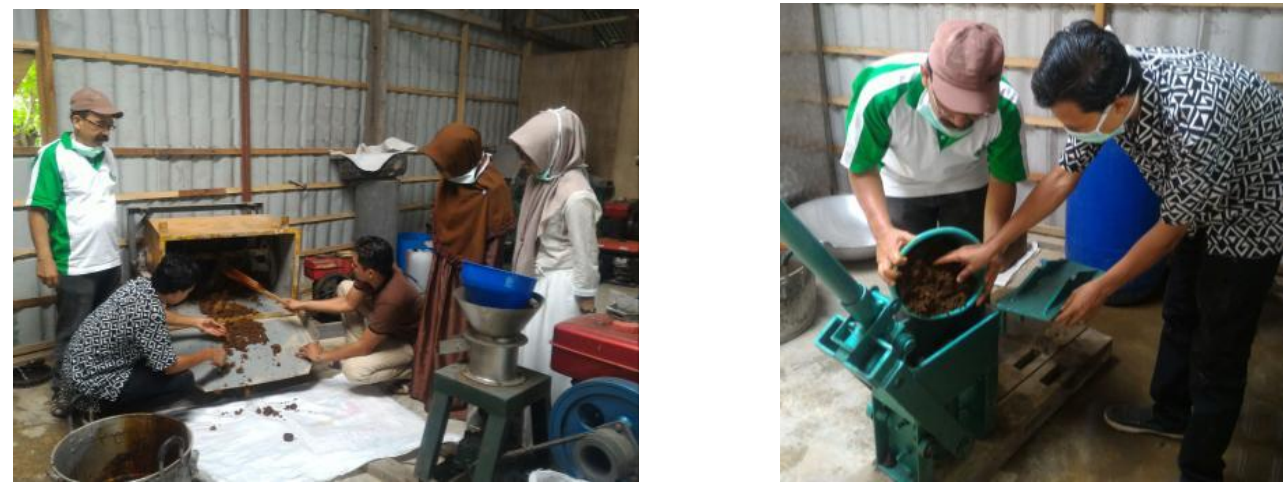

Gambar 2. Pencampuran bahan dasar dengan alat mesin mixer.
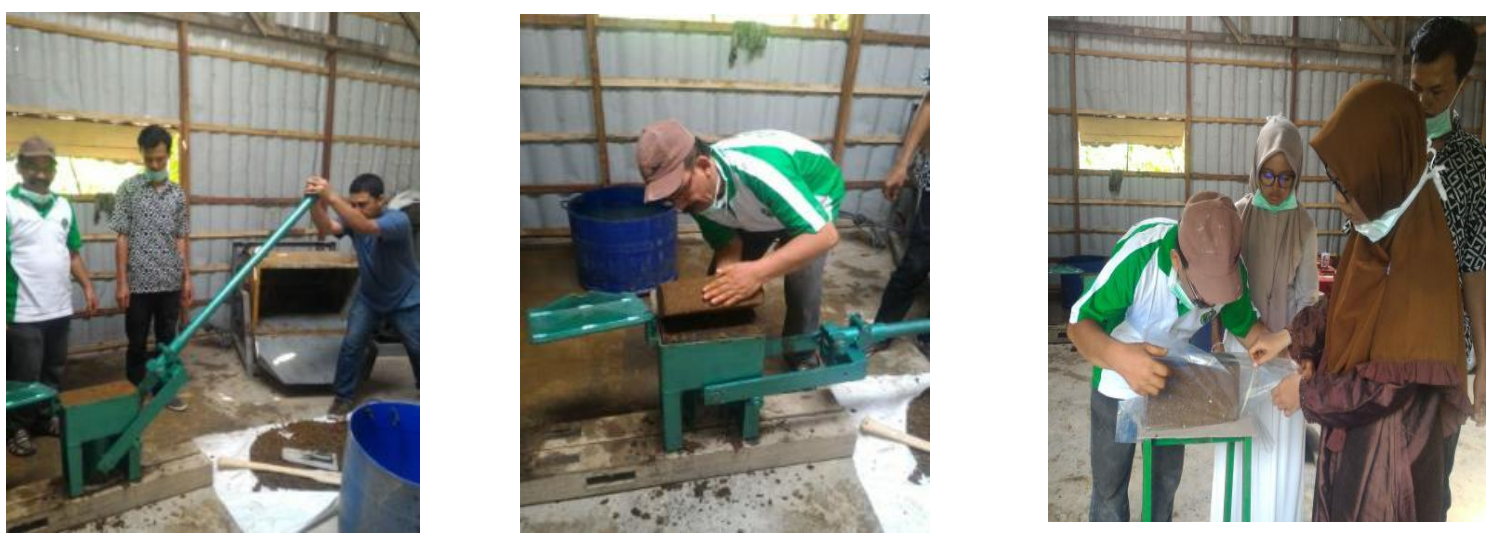

Gambar 3. Bahan nutrient block siap dicetah dengan mesin press. 

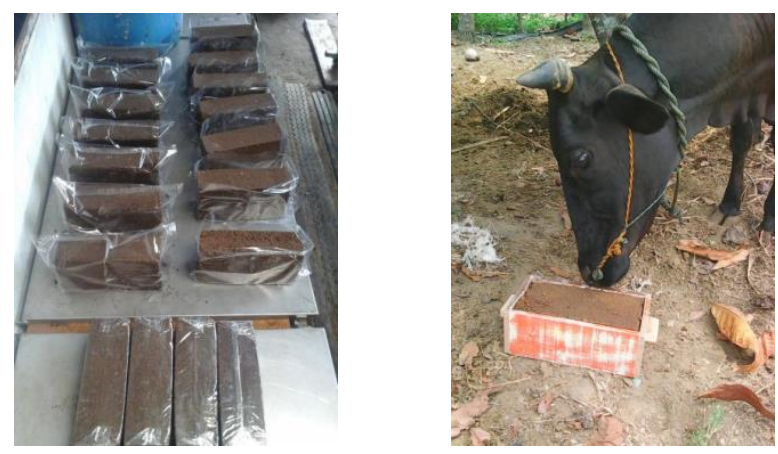

Gambar 4. Hasil cetakan nutrient block dan cara pemberian.

\section{Hasil dan Luaran yang Dicapai}

Berdasarkan permasalahan utama yang dihadapi oleh para mitra, yaitu kesulitan untuk mendapatkan mesin press nutrient block, model mesin pres pakan, teknik formula komposisi pakan persoalan ketergantungan terhadap pakan dari pabrik dengan harga yang relatif tinggi. Penyelesaian masalai ini telah dilakukan serangkaian program kegoatan. Program diawali dengan kegiatan sosialisasi mengenai mesin press nutrient block, pemanfaatan dan pembuatan nutrient block .

Selama pengabdian berlangsung respon dan partisipatif dari masyarakat sangat tinggi. Kegiatan ini telah meningkatkan keterampilan petani/peternak di bidang manajemen dan kesehatan ternak ruminansia, terutama ternak sapi. Produk yang telah dihasilkan berupa mesin press nutrient block dan paakan nutrient block, serta pertambahan berat badan sapi yang lebih baik dibandingkan tanpa pemberian nutrient block.

Para mitra telah mendapatkan manfaat sesuai dengan spesifikasi usaha masing-masing. Mitra industry logam telah mendapatkan pengalaman baru tentang pengembangan industri logam, terutama pembuatan mesin press pakan. Melalui kerampilan ini mitra industri dapat membantu para pelaku usaha pakan ternak yang memerlukan mesin tersebut.

Menggunakan mesin press nutrient block kemampuan produksi dapat ditingkat. Mesin ini dapat memproduksi 100 block pakan /jam. Sehingga waktu dan tenaga mitra produsen pakan bisa lebih efisien. Produsen pakan juga telah memiliki pengetahuan yang baru, terutama formula pakan untuk spesifikasi tertentu seperti nutrient block antiparasit dan nutrient block growth promotor.

Kehadiran nutrient block telah membantu para mitra peternak untuk mendapatkan feed additive sebagai pakan pelengkap ternak sapi mereka. Para peternak dapat memilih jenis pakan yang ditawarkan oleh mitra produsen pakan dengan harga yang terjangkau. Selama masa pembinaan para peternak telah mendapakan manfaat dari kegiatan ini. Performan ternak sapi mereka menjadi lebih baik dari sebelumnya. Melalui kegiatan ini dapat membentuk kegiatan ekonomi usaha yang sinergis dan saling menguntungkan dari para mitra binaan. 


\section{Simpulan dan Saran}

\section{Kesimpulan}

Melalui kegiatan program pengabdian kepada masyarakat berbasis produk ini pengetahuan dan keterampilan para mitra tentang konsep dasar dan prinsip kerja mengenai mesin press nutrient block, formula pakan, cara pembuatan, pengemasan dan pemberian pakan mengalami peningkatan setelah mengikuti program pelatihan.

\section{Saran}

Perlu pendampingan dan pemantauan dari dinas terkait agar kegiatan ini dapat berjalan secara konsisten melalui program-program penyuluhan.

\section{Ucapan Terima Kasih}

Penulis mengucapkan terimakasih kepada ketua Lembaga Penelitian dan Pengabdian kepada Masyarakat Universitas Syiah Kuala atas dana yang diberikan, para mitra Kelompok serta anggota tim pengabdian masyarakat atas kerjasama, sehingga kegiatan ini dapat terlaksana.

\section{Daftar pustaka}

Arenu J. Mumbiangke and Danbaro. G (2014). Growth of beef steers fed on urea-molassesmineral block supplement in Papua New Guinea. Niugini Agrisaens. 6: 33-38.

Danbaro. G, Shengguo Z, Jianlin, H. (2013). Identifying Populations of Papua New Guinea's Indigenous Chickens for Priority. Conservation PNG. Journal of Agriculture, Forestry and Fisheries. 2013. 54: 03-09.

Guesh, F., and M. Urge. 2014. Comparison of supplementing urea-molasses block and ureaatela blocks on body weight change and carcass characteristics of male blackhead ogaden sheep fed natural pasture hay. Journal of Biology, Agriculture and Healthcare. Vol.4, No.20.

Lapauve.L and Danbaro. G (2014). Effects of Urea-Molasses-Mineral-Blocks (UMMB) on the growth performance of goats (Capra hircus) maintained on natural pastures in Papua New Guinea. PNG. Journal of Agriculture, Forestry and Fisheries. 2014. 55: 31-37.

Martel, C. A. E. C. Titgemeyer, L. K. Mamedova and B. J. Bradford. 2011. Dietary molasses increases ruminal $\mathrm{pH}$ and enhances ruminal biohydrogenation during milk fat depression, Journal of Dairy Sciences, 94:3995-4004.

Miller, S. M. and R. P. Thompson. 2003. Developing urea-molasses feed blocks in the Falkland Islands. Livestock Research for Rural Development (15) 3.

Soder,K. J. A. F. Brito, and K. Hoffman (2011), Effect of molasses supplementation and nutritive value on ruminal fermentation of a pasture-based diet, The Professional Animal Scientist, 27:35-42.

Soham , Trivedi and S. Shah. 2014. The effect of cane molasses on cow milk productivity. International Journal of Current Engineering and Technology.

Suharyono1, H. Sutanto, Y. Purwanti, Martanti, A. Agus and R. Utomo. 2014. The effect of urea molasses multi-nutrient and medicated block for beef cattle, beef and dairy cow. Atom Indonesia. Vol. 40 No. 2, $77-87$. 
Wahyudi, A. 2005. Evaluasi Daya Hidup Bakteri Selulolitik dalam Urea Molasses Mineral Probiotik Blok (UMMPB) sebagai Bahan Pembawa. Laporan Penelitian PBI, UMM.

Wahyudi, A. 2006. Evaluasi Penggunaan Urea Molasses Mineral Probiotik Blok (Ummpb) Pada Sapi Perah Laktasi terhadap Produksi dan Kualitas Susu. Jurnal Protein. Vol. 14 No. 2.

Wahyuni, R.S. 2009. Pengaruh Pemberian Urea Molasses Blok dalam Ransum terhadap Hasil Pemeriksaan laboratorium dan Performan Domba. Laporan Pengabdian kepada Masyarakat LPPM UNAIR, Surabaya.

Yanuarto, A.D. Oktawan, D.H. Tambunan, S. Indarjulianto, A. Nururrozi dan Rusmihayati. 2016. Pengaruh Suplemen Molases Mineral Blok Terhadap Kadar kalsium dan Fosfor Sapi Peranakan Ongole Di Gunung Kidul. Seminar Nasional "Peran Dokter Hewan Dalam Peningkatan Kesehatan Hewan, Lingkungan dan Manusia”. FKH UGM Yokyakarta 17 September 2016. 